\title{
Selection OF Heavy Construction Equipment
}

\author{
Nishigandha Davane \\ Department of Civil Engineering \\ SSGB College of Engineering, Bhusawal \\ Prof. P.M.Attarde \\ Faculty of Civil Engineering Department \\ SSGB College Of Engineering, Bhusawal
}

\begin{abstract}
The selection of the appropriate type and size of construction equipment often affects the required amount of time and effort and thus the job-site productivity of a project. It is therefore important for site managers and construction planners to be familiar with the characteristics of the major types of equipment most commonly used in construction. The main consideration in any endeavor is to get the job done according to timeframe and cost limitations. In order to achieve this goal, proper calculation of productivity rates for the fleets while considering variable factors is required.
\end{abstract}

Keywords - productivity, fleets etc.

\section{INTRODUCTION}

A problem which frequently confronts a contractor as he plans to construct a project is selection of the most suitable equipment. He should consider the money spent for the equipment as an investment which he can expect to recover with profit during the useful life of the equipment. A contractor does not pay for the construction equipment; the equipment must pay for itself by earning for the contractor more money than it cost. A contractor can never afford to own all types or sizes of equipment that might be used for the kind of work he does. It may be possible to determine what kind and size of equipment seem most suitable for a given project, but this information will not necessarily justify the purchase of the equipment, he may own a type of equipment that is less desirable than the proposed one, but, it may be of benefit and less expensive than the proposed one.

\section{FACTORS WHICH INFLUENCE THE PERFORMANCE OF CONSTRUCTION EQUIPMENT}

There are several factors that can affect or influence the performance of construction equipment and that can be gathered in the following groups:

\section{Routine delays:}

All those factors that are derived from the inevitable equipment use, no machine can function at maximum power continuously.

Maintenance falls into these kind of delays.

2. Restrictions to optimal mechanic operation:

These originate a reduction effect on production, due exclusively to limitations to its optimal operation. Slopes, angles, heights, cutting depths, etc, are all restrictions of this kind.

3. Site conditions:

Once on site different kinds of factors can affect the performance of given equipment, some are:

a) Physical conditions: topography and geology of the site, geotechnical characteristics of the ground or rocks, etc.

b) Climate: temperature, rain, snow, etc.

c) Localization of the site: how near is the site from urban centers or industrial sites for provisioning.

d) Adaptation conditions: degree of adaptation of the work team can sometimes hinder the performance of the equipment.

4. Direction and Supervision: Organization of the workflow, planning and other management decisions can pose obstacles for maximum performance.

All of these factors were quantified in order to obtain a real production of the equipment. 


\section{ASPECTS OF CONSTRUCTION EQUIPMENTS}

\section{Sources of Construction Equipment:}

Contractors and other users of construction equipment are concerned with a decision as to whether to purchase or rent equipment. Under certain conditions it is financially advantageous to purchase, whereas under other conditions it is more economical and satisfactory to rent it. There are at least three methods under which a contractor may secure the use of construction equipment:

1. Purchase the equipment.

2. Rent the equipment.

3. Rent the equipment with an option to purchase it at a later date.

Each of the three methods has both advantages and disadvantages which should be considered prior to making a decision. If the cost was the only factor to be considered, then an analysis of the cost under each method should give the answer. If other factors should be considered, they should be evaluated and applied to the cost as a basis on which to reach a decision. The correct decision for one contractor will not necessarily apply for another contractor.

\section{ADVANTAGES OF PURCHASING EQUIPMENT COMPARED TO RENTING IT ARE:}

1. It is more economical if the equipment is used sufficiently.

2. It is more likely to be available for use when needed.

3. Because ownership should assure better maintenance and care, purchased equipment should be kept in better mechanical condition.

\section{DISADVANTAGES OF OWNING EQUIPMENT COMPARED TO RENTING IT ARE:}

1. It may be more expensive than renting.

2. Purchasing may require a substantial investment of money or credit that may be needed for other purposes.

3. The ownership of equipment may influence a contractor to continue using obsolete equipment after superior equipment has been introduced.

4. The ownership of equipment designed primarily for a given type of work, may induce a contractor to continue doing that type of work, whereas other work requiring different types of equipment might be available at a higher profit.

5. The ownership of equipment might influence a contractor using the equipment beyond its economic life, thereby increasing the cost of production unnecessarily.

Once the decision is made whether to purchase or rent, the next decision to be made is whether to simply rent or rent with an option to purchase. The latter alternative will result in a higher rental cost as some of the periodic rental charges will be applicable towards the purchase price of the equipment. This is an attractive alternative if the renter of the equipment believes he may have enough use for the equipment to purchase it, but is not too sure that the utilization will be as high as predicted. This kind of rental agreement. If the contractor intends to buy the equipment after renting it for a period of time, then $90 \%$ of the rent charges will be discounted from the total actual cost of the equipment.

\section{CONCLUSION AND DISCUSSIONS:}

This study indicates that construction equipments used on major construction sites have the different aspects which we have to take into consideration while selecting the heavy construction equipments for the different works.

In equipment planning, the following should be considered:

- Equipment should be selected to enhance the operating efficiency of each equipment used in combination. The working capacities of every equipment used in combination should be matched.

\section{REFERENCES}

[1] "Soft" Considerations in Equipment Selection for Building Construction Projects by Aviad Shapira, F.ASCE; and Marat Goldenberg 10.1061/ (ASCE)(0733)(9364)(2007)(133:10)(749)

[2] Cranes for Building Construction Projects Aviad Shapira, M.ASCE; Gunnar Lucko, A.M.ASCE; and Clifford J. Schexnayder, F.ASCE 10.1061/(ASCE)(0733-9364)(2007)(133:9)(690)

[3] Asphalt Mix Design and Construction: A Selection of Possible Pitfalls J.J.E. Liebenberg, D. Rossmann and E. Fletcher

[4] A Study on Resource Planning In Highway Construction K Swarna Kumari, J Vikranth. International Journal of Engineering Research and Applications (IJERA) ISSN: 2248-9622 www.ijera.com Vol. 2, Issue4, July-August 2012, pp.1960-1967 1960

[5] Compaction Monitoring Using Intelligent Soil Compactors, R. Anderegg, Dominik A. von Felten, and Kuno Kaufmann

[6] 3D Equipment Management System for Highway Construction Projects: Conceptual Design By Y.R.Anbhule1 and Prof. M.B. Kumthekar ISSN: 2278-1684, PP: 01-03 
[7] Implementation of GPS Controlled Highway Construction Equipment, Report of April 2007 by Alan P. Vonderohe, Constructions Materials and Support Center University of Wisconsin - Madison. 